\title{
La configuración del nuevo Estado franquista en las imágenes publicitarias
}

\author{
Susana Sueiro SeOANE \\ Profesora Titular de Historia Contemporánea (UNED) ${ }^{1}$ \\ The configuration of the new Francoist State \\ in advertising images
}

\begin{abstract}
RESUMEN
Durante la guerra civil, en los territorios que iban cayendo en poder de las tropas franquistas, fue necesario exteriorizar la adhesión a los principios del bando nacional para evitar aparecer en la lista de sospechosos. En los años de la guerra, y más aún en los de la inmediata posguerra,

el universo ideológico de los llamados «nacionales» —una amalgama donde se mezclaban elementos fascistas y tradicionalistas-impregnó todos los

ámbitos sociales, incluida la publicidad comercial, que se convirtió en una variante

de la propaganda política. Las casas comerciales utilizaron profusamente en sus anuncios la iconografía, las consignas, los símbolos y rituales de la "Nueva España»:

la épica imperial, el nacionalismo españolista, el tradicionalismo católico, la estigmatización de la España republicana,

las banderas bicolores, los escudos nacionales, los brazos en alto..., si bien ello se haría bajo el estricto control del Estado, que revisó y corrigió, a través de los mecanismos de la censura, todos los contenidos difundidos en los medios de comunicación, incluidos los publicitarios, con un celo reglamentista impresionante.
\end{abstract}

\section{SUMMARY}

During the Spanish Civil War, in the territories that were being occupied by the Francoist forces, it was necessary to exteriorise adherence to the principles of the nationalist side, in order to avoid appearing on the list of suspects. During the war, and even more so in the immediate post-war years, the ideological universe of the so-called 'nationalists'-an amalgam in which fascist and traditionalist elements mixed-impregnated all social spheres, including commercial advertising, which became a variant of the political propaganda. Businesses extensively used the iconography, slogans, symbols and rituals of the "New Spain» in their advertising: the Imperial epic, Spanish nationalism, Catholic traditionalism, the stigmatisation of Republican Spain, bicolour flags, national escutcheons, raised arms..., although this would be done under the strict control of the State, which revised and controlled, through the censorship mechanisms, all of the contents delivered by the media channels, including advertising, with an impressive regulatory zeal.

1 Este trabajo forma parte de la investigación realizada por la autora para la exposición «Posguerra: publicidad y propaganda, 1939-1959», organizada por el Círculo de Bellas Artes y la Sociedad Estatal de Conmemoraciones Culturales en mayo de 2007. Véase, Susana Sueiro (Ed.): Posguerra: Publicidad y Propaganda. Madrid, 2007. Se adjunta CD en la portadilla de la revista. 
PALABRAS CLAVE

Franquismo, España nacional,

propaganda política, publicidad comercial.

\section{KEY WORDS}

Francoism, nationalist Spain, political propaganda, commercial advertising.

Las diversas fuerzas de la derecha española que se comprometieron con la sublevación militar en julio de 1936 sufrirían a lo largo de la guerra un proceso de radicalización y fascistización, acentuando progresivamente sus perfiles antidemocráticos. La inicial indefinición política de los insurrectos dio paso rápidamente a la concentración del poder en la persona del general Franco, que se hizo con el mando único, consiguió ser nombrado Generalísimo, o sea, jefe militar supremo, y jefe del Estado español, desde el 1 de octubre de 1936, y, finalmente, jefe del partido único, desde abril de 1937. Todo ello le daba un poder absoluto que pronto derivó hacia un desaforado culto a su persona.

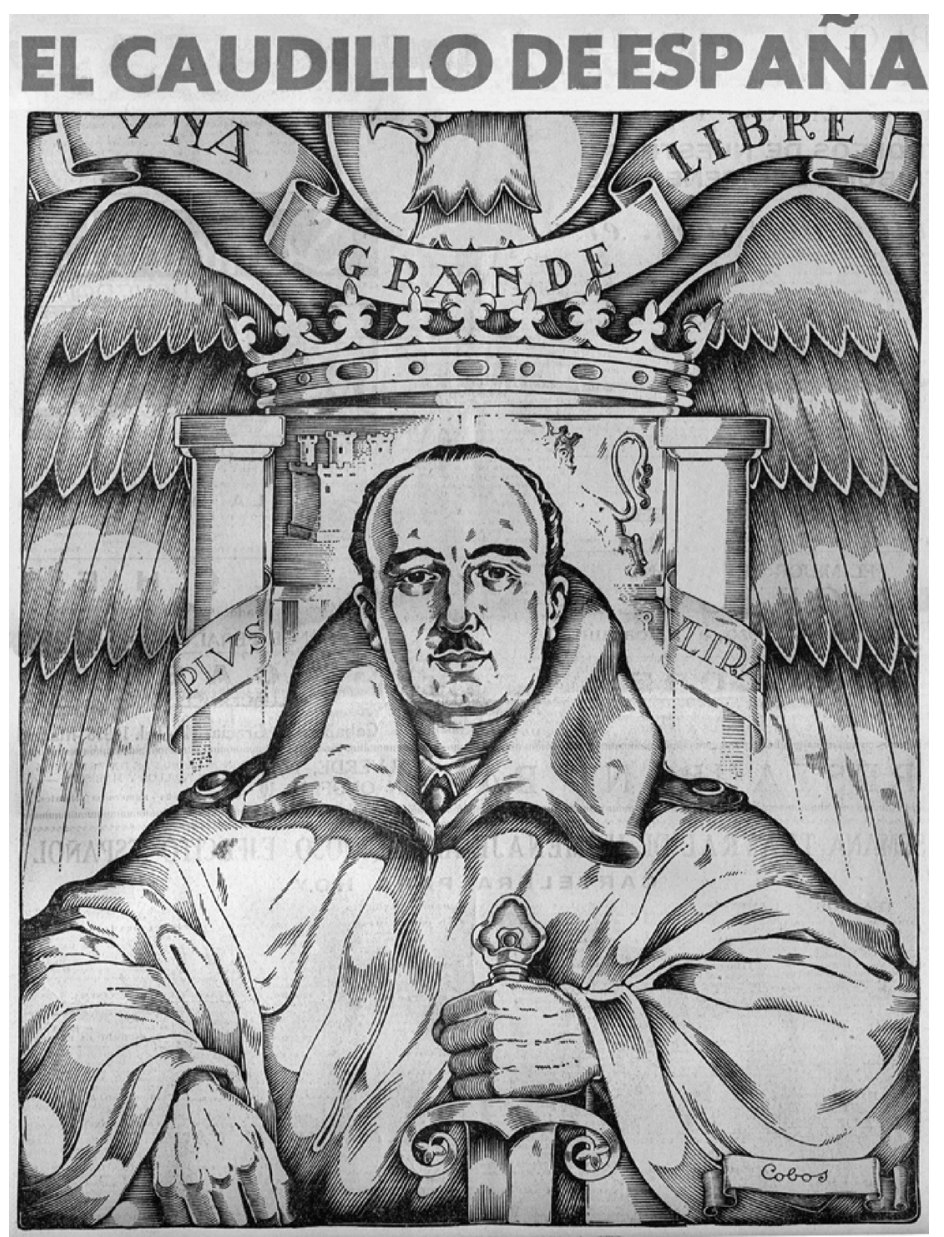


El decreto de Unificación de abril de 1937 convirtió a la Falange en el partido oficial y único, cambiando su nombre - ya no sería FE sino FET- para reflejar su fusión con el otro principal partido de la derecha, el partido Carlista o Tradicionalista. Falange y Requetés se integraron en una sola organización, síntesis o amalgama de las concepciones histórico-políticas tanto fascistas como tradicionalistas. En adelante sería Falange Española Tradicionalista y de las JONS y su máximo jefe, Franco, el Caudillo, salvador de España en la Cruzada.

En el ejercicio de su omnímodo poder, Franco, muy hábil siempre a la hora de contraponer y equilibrar el peso de las distintas fuerzas que le apoyaban, para evitar el excesivo crecimiento de una sola opción que pudiera hacer sombra a su poder personal, se apoyó en tres pilares básicos: el Ejército, la Iglesia y el partido único, FET y de las JONS. El objetivo de Franco durante la guerra no fue sólo ganarla sino construir un nuevo Estado. $Y$ en ese nuevo Estado que se fue configurando en la zona nacional durante la guerra civil, el proyecto fascista y totalitario tuvo una gran influencia.

Franco utilizó la glorificación de la figura de José Antonio Primo de Rivera, ejecutado en la cárcel de Alicante en 1936 —el héroe, el Ausente, el mártir-para legitimar el Alzamiento. La doctrina nacionalsindicalista creada por José Antonio se convirtió en el fundamento de los nacionales. La liturgia, la retórica, las canciones, las invocaciones épicas de Falange, fueron utilizadas profusamente por el bando franquista durante la guerra civil, e iban a seguir siendo elementos fundamentales del machaqueo propagandístico de la «nueva España».

La España nacional es una España de símbolos, que impregnan todos los ámbitos sociales, también la publicidad comercial, que se convierte en una variante de la propaganda política. Durante la primera fase nacional-sindicalista del franquismo, fue tal la politización de la vida social que los anuncios y carteles comerciales fueron en muchas ocasiones simples derivados del cartel político. Bien fuese por convicción o por obligación, los anunciantes incluyeron de forma muy explícita mensajes políticos propagandísticos.

La iconografía del bando nacional sería explotada hasta la saciedad. En primer lugar, la bandera nacional bicolor, roja y gualda, «los dos colores benditos, sin mezcla de morado alguno», esto es, la bandera «auténtica» "de la Unidad española», en contraposición al «trapo tricolor ${ }^{2}$ o el «harapo,» como despectivamente fue con frecuencia calificada la bandera republicana. Junto a la enseña nacional, solían aparecer la falangista, roja y negra, y la tradicionalista, blanca, con la cruz roja de San Andrés. Eso sí, la bandera española siempre unos centímetros por encima de las otras dos ${ }^{3}$.

2 Así denominaba Juan Ignacio Luca de Tena a la bandera republicana. Véase, $A B C, 1$ de abril de 1939.

3 Hemos encontrado una solicitud de autorización de un cartel de propaganda de la Segunda Feria Nacional de Muestras de Zaragoza, de septiembre de 1942, denegada por no haber respetado el orden de prelación de la bandera nacional, del partido y tradicionalista. Véase, AGA, (3) 48 21/62, C-56-76. 

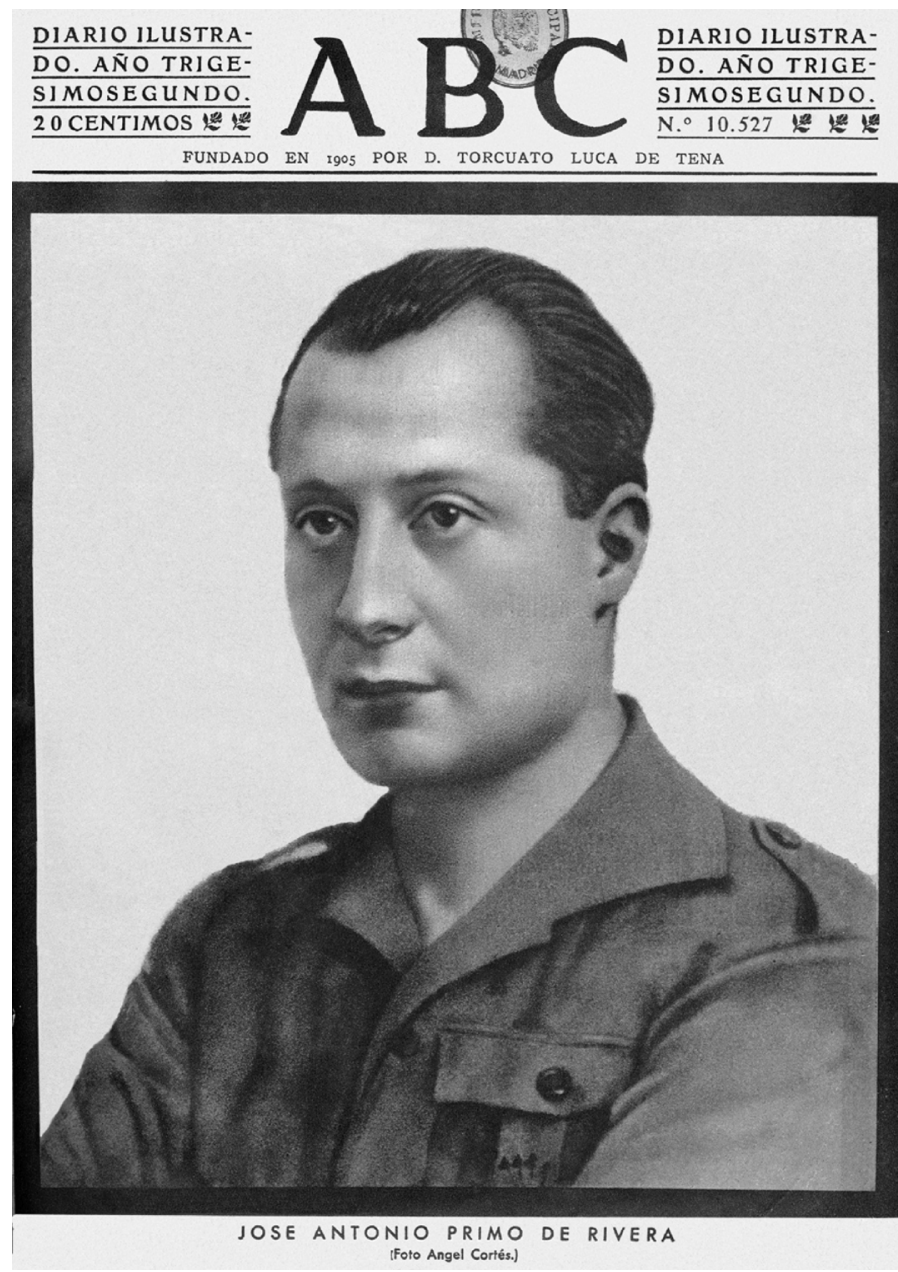

No sólo los carteles de propaganda política sino también los de publicidad comercial se llenaron de banderas y de los colores predilectos - sobre todo el rojo y gualda - del bando nacional (imágenes 1-3) ${ }^{4}$.

Hubo también una abrumadora presencia de los himnos. Un decreto de febrero de 1937 había establecido como himno nacional la Marcha Granadera y otorgó rango de cantos nacionales al Cara al Sol falangista, al Oriamendi carlista y al himno de la Legión. Un ejemplo es el anuncio de dentífricos Orive en que, junto al mapa de España, se muestran los signos e himnos falangistas y carlistas (imagen 4).

${ }^{4}$ La totalidad de las imágenes pueden verse en el CD adjunto a la revista. 


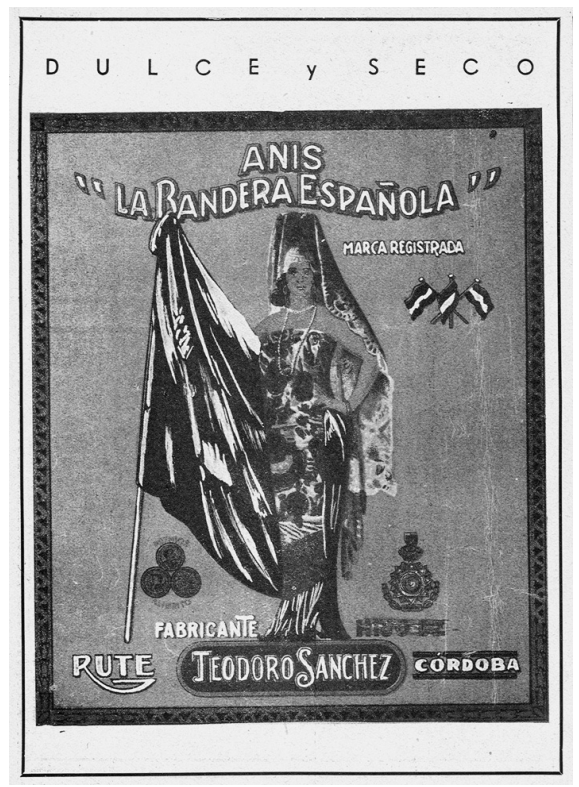

El ritual del saludo fascista también está muy presente en la publicidad (imágenes 5-7). Un decreto de abril de 1937 había establecido el saludo nacional «constituido por el brazo en alto, con la mano abierta y extendida y formando un ángulo de cuarenta y cinco grados», obligatorio ante el paso de la bandera española o la interpretación del himno y los cantos nacionales.

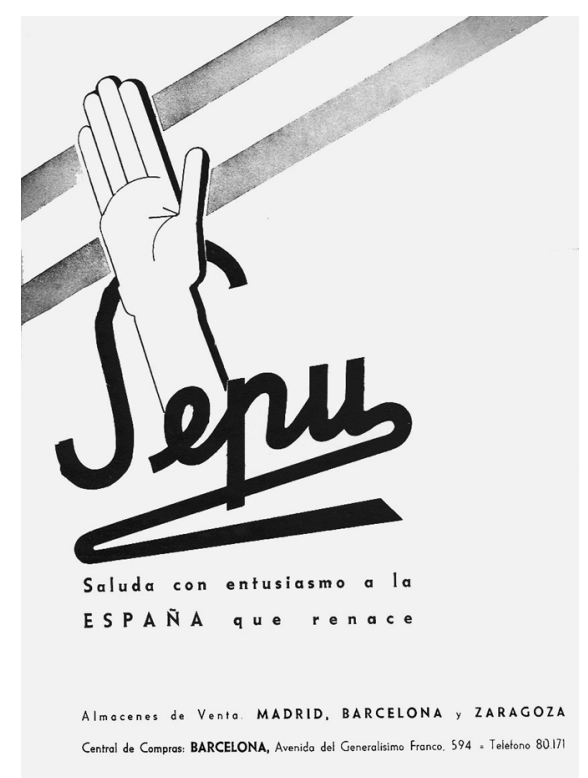


Y, por supuesto, también hay una profusa utilización del escudo oficial con el águila imperial, el yugo y las flechas de los Reyes Católicos y el lema «Una, Grande, Libre» (imágenes 8-9). Un decreto de febrero de 1938 estableció con las siguientes palabras el nuevo Escudo de España: «El águila que desde Roma viene siendo símbolo de la idea imperial y que figuró en el blasón de España en las épocas más gloriosas de su historia. El haz y el yugo de los Reyes Católicos (entonces, como ahora, emblema de unidad y disciplina) cuya adopción como distintivo constituye uno de los grandes aciertos de nuestra Falange que ha querido adoptar el mismo conjunto heráldico, el escudo con el haz y el yugo, «como testimonio de un momento histórico que se parece a éste que ahora vivimos, en lo difícil de la lucha, en el optimismo triunfante, en los anhelos imperiales", según rezaba el decreto de 2 de febrero de 1938 que estableció el nuevo Escudo de España.

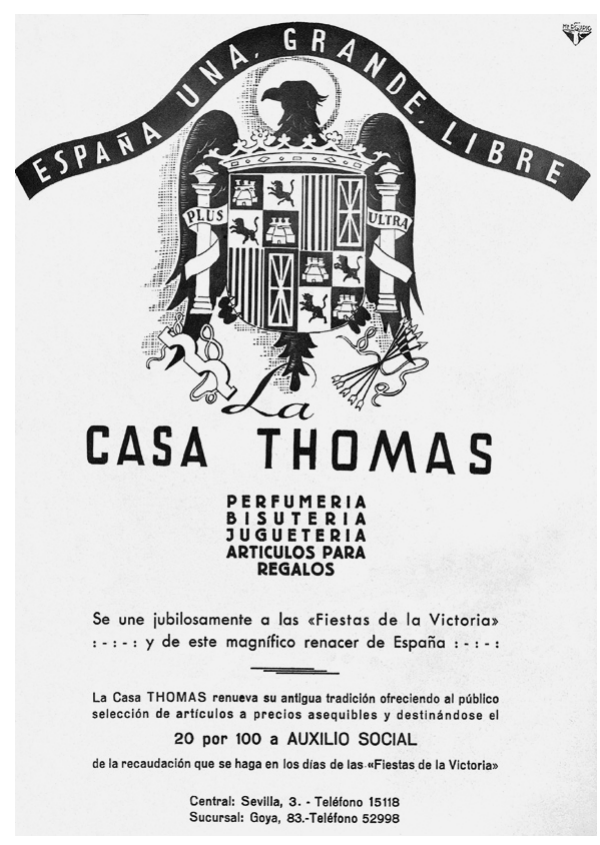

Todos estos símbolos, además de multitud de gritos, clamores y eslóganes - AArriba España!, «Franco, Franco, Franco»- son incorporados en la zona nacional a la publicidad comercial, que, como hemos dicho, se convierte en una variante de la propaganda política. El manejo de la fraseología de los llamados nacionales por parte de las casas comerciales en sus anuncios fue muy habitual en el transcurso de la guerra, y lo seguiría siendo en los primeros años del franquismo. A medida que las tropas franquistas avanzaban, en los territorios que iban cayendo en su poder, se hacía necesario exteriorizar la adhesión a los principios del ban- 
do nacionalista para evitar aparecer en la lista de sospechosos. Teniendo en cuenta que la «desafección» podía suponer depuración, cárcel e incluso ejecución, no es difícil comprender que todo el mundo se apresurase a mostrar fidelidad a los nuevos gobernantes. Perfumerías, corseterías, mantequerías, bares, cervecerías, cafés, restaurantes, almacenes de tejidos, librerías, bancos, compañías de seguros..., todos saludaron en sus anuncios al insigne Caudillo, salvador de la Patria, y a su glorioso Ejército Nacional, al grito de «¡Viva España!, ¡Viva Franco!, ¡Arriba España! (imágenes 10-15). El 19 de mayo de 1939, día del primer desfile de la Victoria en el madrileño Paseo de la Castellana, el conocido anís La Castellana no tuvo necesidad de recurrir a eslóganes para anunciarse. Bastaba con la expresiva imagen de una formación de aviones caza del ejército de Franco surcando el cielo. Las palabras sobraban (imagen 16).

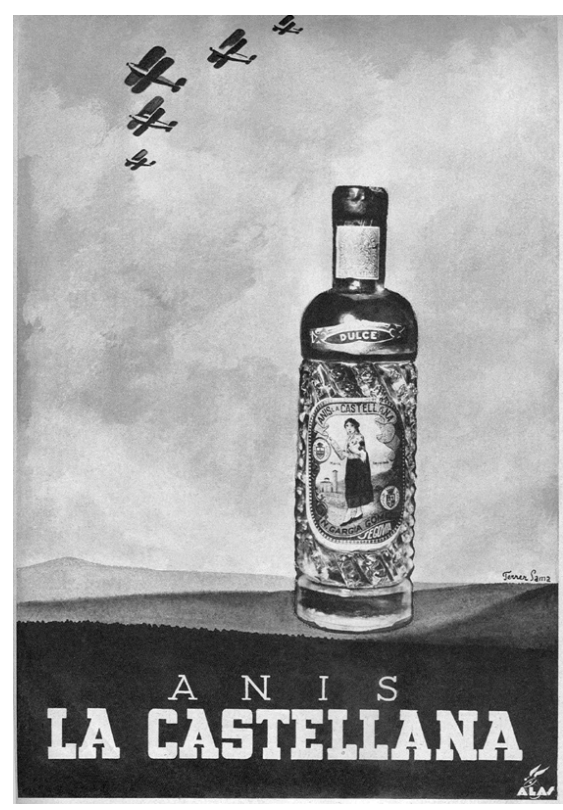

En la España que iba quedando en poder de los nacionales, fue tal el abuso de los comerciantes deseosos de congraciarse con los nuevos gobernantes que, ya en 1937, se dictaron medidas muy restrictivas para la utilización de los héroes, mártires y otras figuras destacadas del Movimiento Nacional como marcas comerciales o títulos de establecimientos y, en general, como reclamo publicitario ${ }^{5}$.

5 Orden de 29 de octubre de 1937 (BOE del 2 de noviembre), que se recordará en repetidas ocasiones en el futuro, por ejemplo, en las «Instrucciones sobre censura de insignias, emblemas, nombres de héroes, mártires y figuras destacadas del Movimiento Nacional, rotulación de calles, plazas, etc., e iniciativas de estatuas y monumentos» de la Delegación Nacional de Propaganda de la Vicesecretaría de Educación Popular, de 21 de octubre de 1942. AGA, (3) 60-21/806. 
Desde luego, el nuevo Estado de pretensiones totalitarias que fue configurándose en los años de la guerra, revisó y corrigió, a través de los mecanismos de la censura, todos los contenidos difundidos en los medios de comunicación, incluidos los publicitarios, con un celo reglamentista impresionante, a juzgar por la numerosa aunque desgraciadamente fragmentaria documentación conservada en el Archivo General de la Administración $n^{6}$. Se dispuso que cualquier fabricante que quisiera poner a la venta objetos o productos con los colores, armas, banderas, emblemas, lemas, consignas, símbolos, nombres y episodios de la España nacional, tenía la obligación de solicitar previamente la autorización a un departamento de Censura plástica. Hemos podido comprobar que muchas de las solicitudes enviadas al Departamento de Plástica del Servicio Nacional de Propaganda fueron denegadas por pretender utilizar símbolos o emblemas franquistas en productos comerciales, por no ajustarse a los cánones de pulcritud, elegancia y sobriedad que exigía la Revolución Nacional-Sindicalista. Fue denegada, por ejemplo, la petición de Alfonso Orlando, de Santoña (Santander) ${ }^{7}$, para usar el escudo y la bandera nacionales en sus envases de conservas de pescado (imagen 17). Se prohibió, asimismo, el «Coñac Generalísimo», cuya etiqueta reproducía una foto de Franco con fajín y bastón de General, o un vino con la inscripción «El Caudillo, vino de la Victoria», cuya etiqueta era una silueta de Franco. Pero sí se autorizaron otras, probablemente porque los solicitantes eran importantes comerciantes, adictos a la causa nacional. Por cierto que los solicitantes, en los escritos que dirigían a la Delegación Nacional de Propaganda, se despedían siempre con la frase:

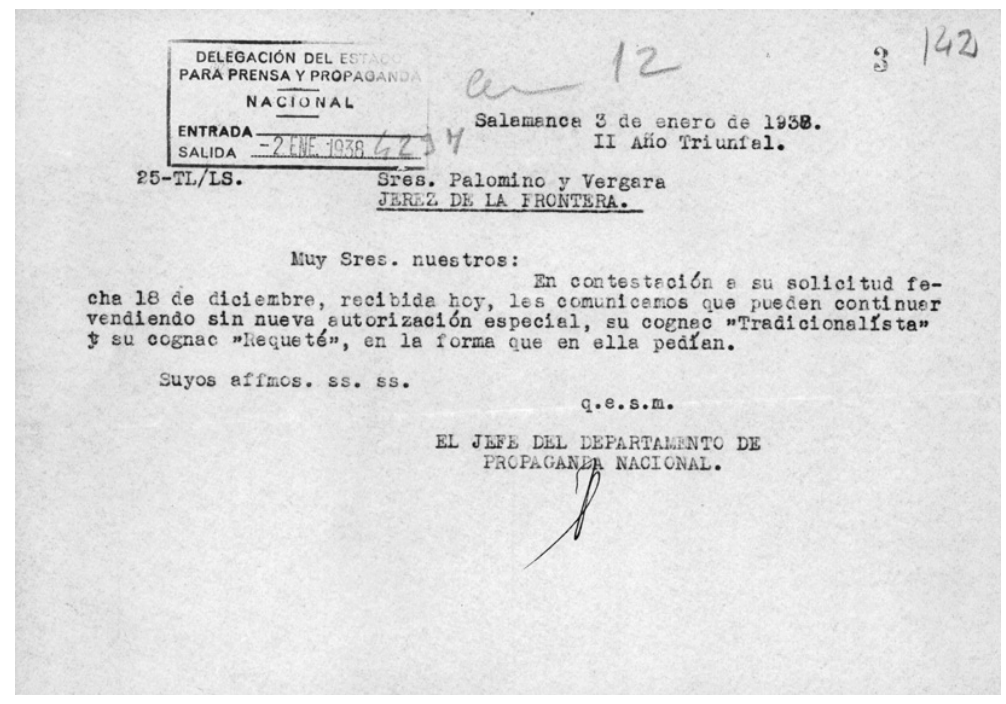

${ }^{6}$ AGA, Sección de Censura del Servicio Nacional de Propaganda integrado en la Vicesecretaría de Educación Popular de la Secretaría General del Movimiento.

7 Véase, AGA, (3) 48-21/64. 
«Saludamos brazo en alto, por Dios, por España y su Revolución Nacional-Sindicalista». Se autorizaron los anises «Viva España», cuya etiqueta era una bandera nacional, solicitado por un fabricante de Soria, y el anís «Bandera Española», de Córdoba. Un fabricante de caramelos, peladillas y grageas de Málaga fue autorizado, al ser ocupada la ciudad por las tropas nacionales, a vender caramelos con los nombres de "Salvación» y «Requeté», con reproducción de banderas, emblemas, himnos y canciones patrióticas (imagen 18). Asimismo, se autorizó el fino «Tradicionalista» y el coñac «Requeté» de una bodega de Jerez de la Frontera (imágenes 19-20).

Se autorizó también el famoso «Imperial Toledo, vino de héroes», de González Byass $^{8}$, en referencia al asedio, en 1936, de la fortaleza toledana del Alcázar, uno de los grandes mitos de la Cruzada, la gesta quizás más representada en la iconografía franquista (imágenes 21-23). A finales de septiembre de 1936, se liberó Toledo en cuyo Alcázar permanecía sitiado desde julio el coronel Moscardó, lo que tuvo una profunda significación propagandística para los nacionales, que iban a explotar al máximo. El nombre comercial «Alcázar» tuvo desde luego gran éxito. La gesta del Alcázar dio por ejemplo nombre a un diario de la noche y a muy diversos

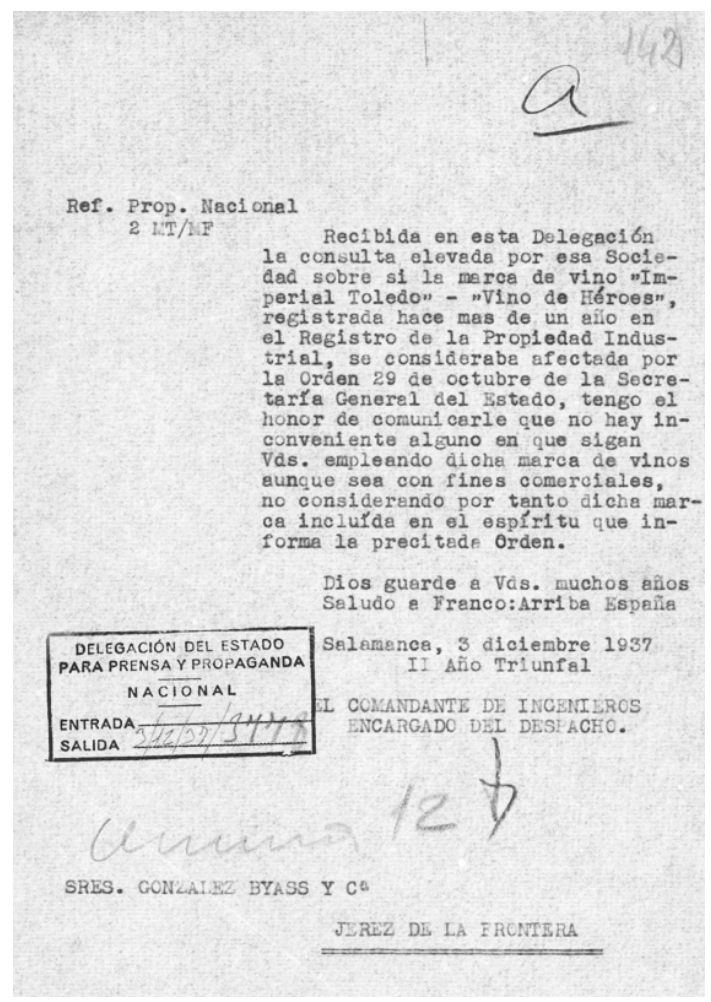

8 Véase el expediente en AGA, (3) 48 21/62. 
establecimientos comerciales como una sombrerería, una fábrica de cervezas o un cine (imágenes 24-26).

En cualquier caso, la publicidad utilizó durante la guerra muchos nombres y eslóganes que hacían alusión a la España nacional: «Patria», «Patria hispana», «18 de Julio», «Cruzada», «triunfal», «invicto», «victoria» (imágenes 27-29), y, por supuesto, «imperial» e «imperio», vocablos que proliferaron al mismo tiempo que Franco afirmaba la voluntad imperial de España.

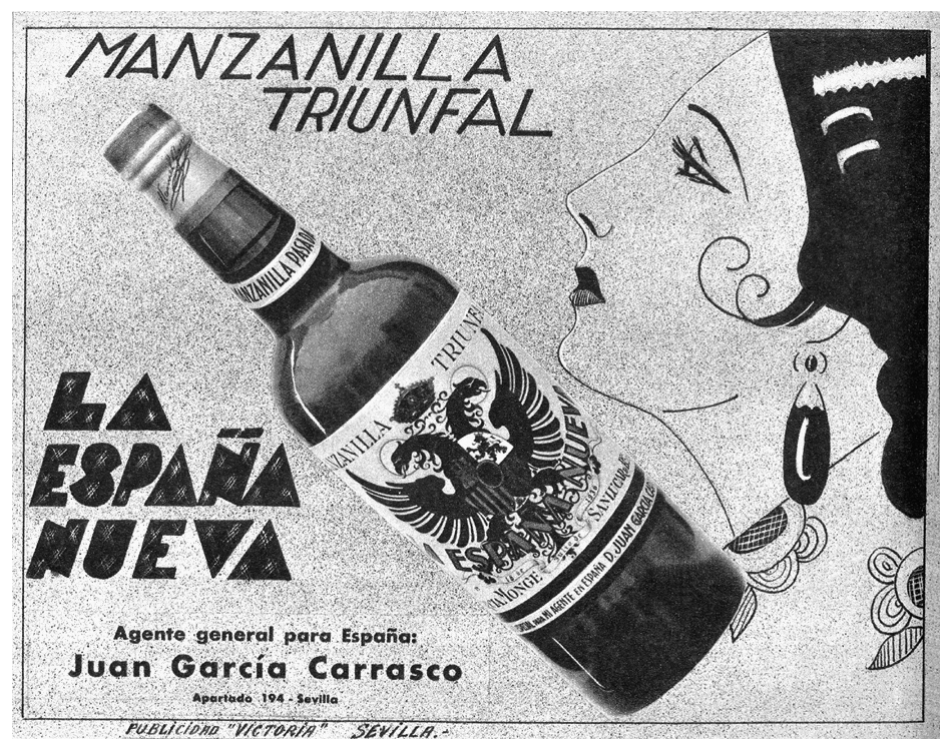

La profusión de lo «imperial» es especialmente llamativa. La ideología imperialista, la idea de engrandecimiento y expansión, fue un elemento esencial del bando franquista. España ya había sido Imperio y, por tanto, podía volver a serlo. La esencia histórica de lo hispano era el Imperio. España debía recuperar su gran misión histórica, «la unidad de destino en lo universal», según frase de José Antonio. Uno de los puntos de Falange rezaba: «Tenemos voluntad de Imperio». Los aires imperiales españoles estuvieron ya muy presentes en la ideología del bando nacionalista durante la guerra civil aunque, por supuesto, al estallar la segunda guerra mundial, al hilo de las victorias alemanas de 1940, se incrementaron sobremanera.

Esta épica imperial caló también en la publicidad: el Hotel Inglés de la calle Echegaray de Madrid pasó a denominarse Hotel Imperio inmediatamente después de acabada la guerra (imagen 30 ). El cine madrileño Madrid-París se transformó en Cine Imperial (imagen 31). No es extraño, como nos recuerda Rafael Abella, que la agencia de publicidad que puso en circulación muchos de esos 
«anuncios-propaganda» se llamase también Imperio'. Transportes Imperio, corsetería La Imperio, perfumería Imperio, zapatos La Imperial, Tintes Imperio, Garaje Imperial, Galletas Imperial, Agua Imperial, Imperial Films, Academia Imperio, café o cervecería Imperial... hubo por entonces toda una auténtica fiebre imperial (imágenes 32-35).

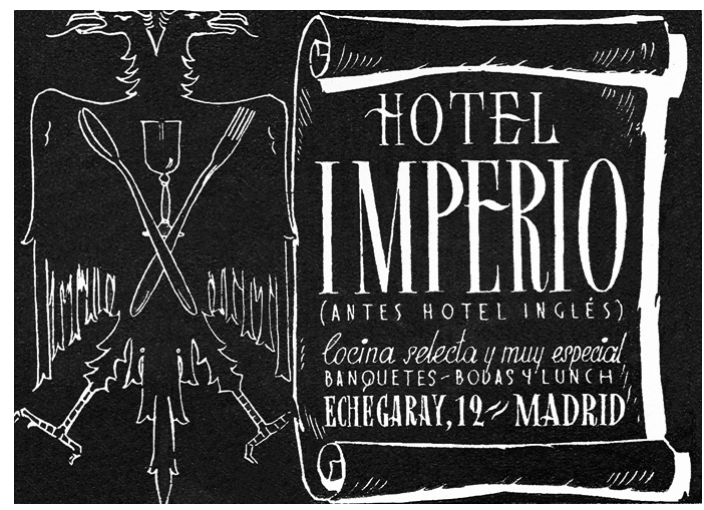

Hay, en definitiva, una amalgama de símbolos y lemas que conforman el universo ideológico de los «nacionales» donde se mezclan elementos fascistas, como el tema imperial, junto con otros tradicionalistas, típicos del pensamiento reaccionario tradicional, como el nacionalcatolicismo. La forzada unificación política e ideológica dio lugar a una síntesis ideológica en que se mezclan valores católicos y tradicionales junto a los estrictamente fascistas que abogaban por una revolución. Hubo un intento de conciliar los valores e ideas, a veces dispares, procedentes de las distintas corrientes que convergen en el bando nacionalista. Aunque las pugnas y conflictos saldrán muchas veces a relucir, una lucha cuyo objetivo era básicamente conseguir cuotas de poder, había en aquellas distintas fuerzas «nacionales» elementos comunes y, además, en alguna medida, acabaron impregnándose unas de los valores de las otras ${ }^{10}$.

Entre los valores comunes estaba el calificar al liberalismo como el mal absoluto, el causante de la decadencia española y del abismo en que España había acabado por precipitarse con la Segunda República. El nefasto liberalismo, responsable según Franco de todas las desgracias nacionales, ocupaba un lugar central entre los más perniciosos virus extranjeros. «Democracia, masonería, socialismo, anarquismo, comunismo, separatismo, todos los recientes males de España tenían su fuente en el liberalismo del siglo XIX»11. Recién acabada la guerra,

9 ABELLA, R.: La vida cotidiana bajo el régimen de Franco. Barcelona, Argos Vergara, 1985, p. 23 y 34-35.

10 Véase SAZ, I.: España contra España. Los nacionalismos franquistas. Madrid, Marcial Pons, 2003.

11 JULIÁ, S.: Franquismo. El juicio de la historia. Madrid, Temas de Hoy, 2000, p. 90. 
el 2 de mayo de 1939, una particular «fiesta del libro» en Madrid consistió en la quema de una montaña de volúmenes: «Con esta quema de libros -explicaba Arriba - también contribuimos al edificio de la España Una, Grande y Libre. Condenamos al fuego a los libros separatistas, liberales, marxistas, a los de la Leyenda negra, a los anticatólicos, a los del romanticismo enfermizo, a los pesimistas, a los del modernismo extravagante, a los cursis, a los cobardes pseudo-científicos, a los periódicos chabacanos...».

El expurgo de libros se extendió a escritores que en principio parecerían inocuos para la causa nacional. La España republicana se estigmatizó con terribles imágenes sobre la «mugre» roja, la «rapiña» marxista, la España «enfangada en la criminal charca del marxismo», el mito de la anti-España instigado desde el bando franquista a través de la propaganda. La cultura española, que había alcanzado su plenitud entre 1900 y 1936, iba a ser cortada de raíz, acusada de ser espuria y extranjera.

Había llegado la hora de afirmar el verdadero «espíritu español» leyendo «buenos libros» (imagen 36) y desterrando todo lo extranjero, causa de la división entre los españoles.

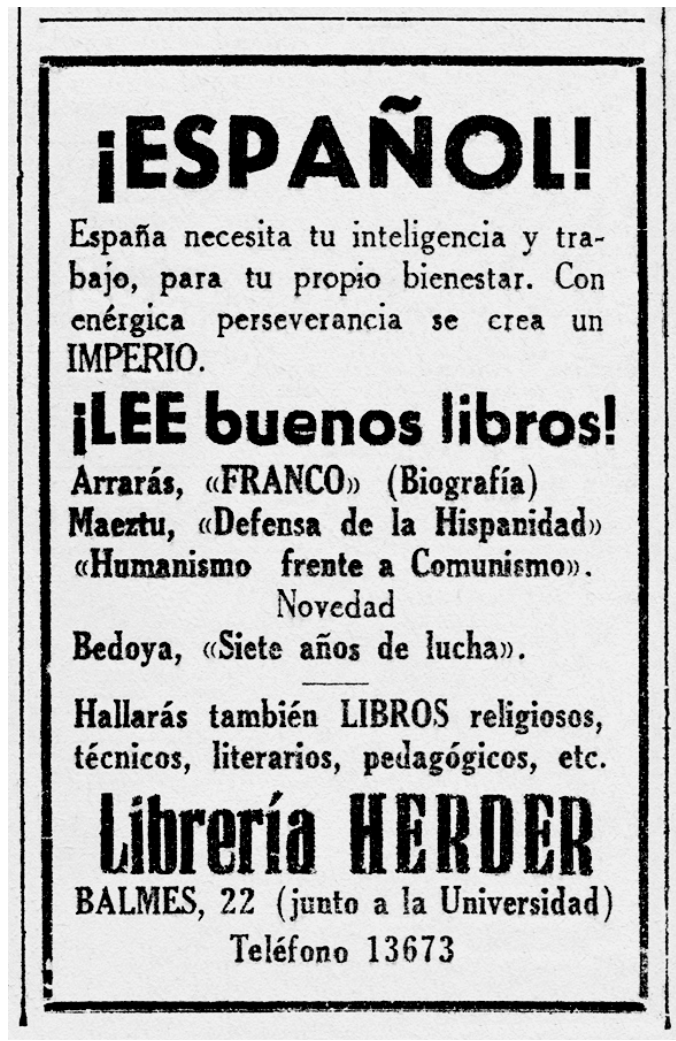


El verdadero espíritu español había que buscarlo en tiempos remotos, de la Reconquista hasta el Siglo de oro. Los franquistas idealizaron en concreto el reinado de los Reyes Católicos, considerado símbolo de la unidad nacional, expresión de la grandeza histórica española, paradigma de las glorias nacionales del pasado. Había sido el momento de «la consumación de la Reconquista, la fundación de un Estado fuerte e imperial, el predominio en Europa de las armas españolas, la unidad religiosa, el descubrimiento del Nuevo Mundo, la iniciación de la inmensa obra misional de España...».

La publicidad va a utilizar hasta la saciedad esas referencias al pasado glorioso (imágenes 37-38) y será muy habitual anunciar los más variados productos con los nombres y representaciones de las carabelas del Descubrimiento surcando el océano (imágenes 39-40).

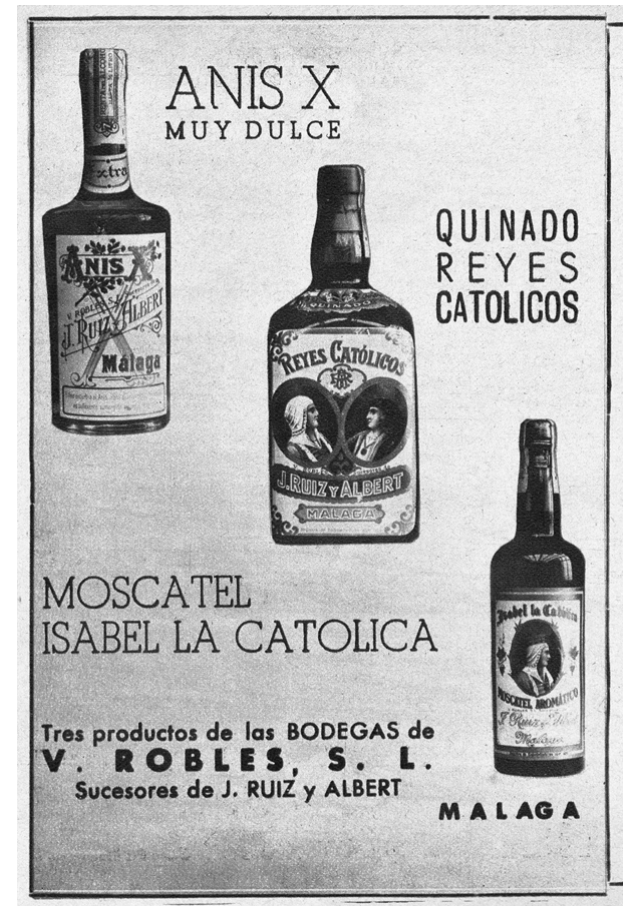

Junto al reinado de los Reyes Católicos, el siglo más reivindicado fue el Siglo de Oro, el siglo XVI, los reinados de Carlos V y sobre todo Felipe II. Son casi obsesivas las referencias al Imperio católico español de aquella época. Hay un mito, el del renacimiento de España, el amanecer imperial. La vuelta al muy católico e imperial siglo XVI. También el mito de Castilla como quintaesencia de España, Castilla como depositaria y responsable de la grandeza pasada y futura de Espa- 
ña, con la propuesta, desde 1938, de celebrar el milenario de Castilla, que finalmente se celebró, ya en 1943 (imagen 41).

El bando nacional aspiraba asimismo a imponer el nacionalismo español rechazando todo "extranjerismo", término que incluía también las lenguas de otras comunidades españolas distintas de Castilla. La España «Una» no admitía disensiones. A medida que las ciudades catalanas fueron cayendo en poder de las tropas nacionales fue habitual que se colgase o escribiese en alguna pared el letrero «Si eres español, habla español», o «habla el idioma del Imperio». Hubo una general satanización de todo lo extranjero y una obsesión por españolizar todo, incluidas las costumbres, la moda, el baile o la música. Sobre la música hemos encontrado en el AGA algunas circulares que no tienen desperdicio. Si los himnos patrióticos y las canciones populares españolas cumplían una importante función en el engrandecimiento de la Nación, "cuando se olvida nuestra música y se comienza la importación de la extranjera, viene con ella el materialismo, la bajeza y la frivolidad, y como nos demuestra la historia, comienza la decadencia». Las circulares de censura radiofónica prohibían terminantemente retransmitir la llamada música «negra», los bailables "swing» o cualquier otro género de composiciones cuyas letras estén en idioma extranjero, o por cualquier concepto puedan rozar la moral pública o el más elemental buen gusto». En la publicidad comercial se prohibió también el empleo de los vocablos extranjeros, considerados infamantes y perniciosos, en rótulos, muestras y anuncios, o como denominaciones de establecimientos mercantiles, industriales, de recreo, hospedaje, alimentación, espectáculos y otros semejantes. Así, el Hotel De France de Valladolid, por ejemplo, pasó a llamarse Hotel Fernando e Isabel (imagen 42) ${ }^{12}$.

Sólo el imperio económico alemán en España (un entramado de cientos de empresas llamado Sofindus) creado en 1938 por Johannes Bernhardt, oficial de las SS y uno de los alemanes más influyentes en la España franquista, que durante la guerra mundial abastecería a Alemania, tuvo amplia cabida en la publicidad. Las empresas alemanas se anunciaron con una publicidad que destacó tanto por su abundancia como por la gran calidad de su diseño gráfico y la rotundidad de sus mensajes. Los famosos Almacenes Alemanes de la plaza Universidad de Barcelona, creados en 1917, se llenaron de banderas nazis en cuanto Barcelona cayó en poder del bando nacional (imagen 43).

Y, junto a los nombres emblemáticos de la «Nueva España», también llegaron a la publicidad sus personajes característicos - los falangistas, los militares, los curas - con sus uniformes y sus emblemas. Repasando las publicaciones de la

12 Son muchos los autores que se han referido a esta campaña que las autoridades franquistas emprendieron contra las «infamantes y perniciosas» palabras extranjeras y a favor de una prosa genuinamente hispánica. Véanse, por ejemplo, ABELLA, R.: Por el Imperio hacia Dios. Crónica de una posguerra. Barcelona, Planeta, 1978, p. 26-27; VIZCAÍNO CASAS, F.: La España de la posguerra, 1939-1953. Barcelona, Planeta, 1975, p. 40; GUBERN, R.: Viaje de ida. Barcelona, Anagrama, 1997, p. 33; MARTíN GAITE, C.: Usos amorosos en la España de posguerra, p. 31; o SINOVA, J.: La censura de prensa en el franquismo. Madrid, Espasa Calpe, 1989. 


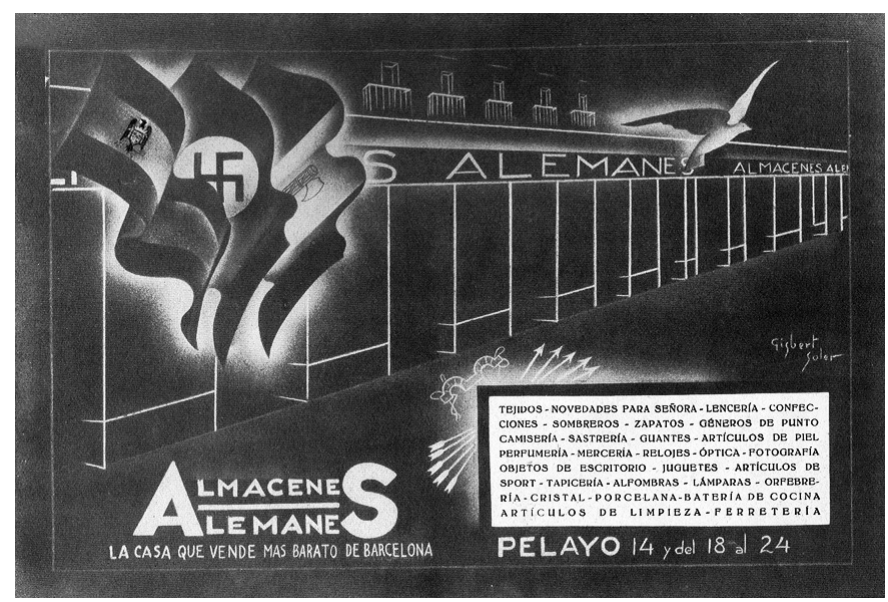

época, resulta abrumadora la cantidad de anuncios de tiendas especializadas en uniformes, correajes, cinturones, distintivos de mando, insignias, medallas, condecoraciones, galones, fajas, fajines, charreteras, etc. (imágenes 44-45). Insignias metálicas para las solapas, con el yugo y las flechas, con las aspas de Borgoña, con los colores de la bandera nacional..., escudos de tela para pegar a las ropas, de todo ello se vendió muchísimo ${ }^{13}$.

Pero, además de sus uniformes y emblemas, los propios personajes -flechas, pelayos y cadetes del Frente de Juventudes, con sus camisas azules falangistas y sus boinas rojas carlistas (imágenes 46-48); militares, con sus uniformes, sus botas altas y sus capotes (imagen 49) - aparecen como protagonistas de anuncios de los más variados productos, desde polvos de talco y flanes para los pequeños flechas y pelayos hasta coñacs, anises y champañas para los brindis por la Patria de los más adultos.

Otro de los componentes fundamentales del nuevo Estado que se fue configurando durante la guerra fue, sin duda, la Iglesia. La Iglesia apoyó a Franco y consiguió erigirse en una fuerza poderosísima, factor de legitimación de la contienda y punto de referencia común para todas las fuerzas de la derecha que componían el bando nacionalista. La terrible persecución de que la Iglesia y los religiosos fueron objeto en la zona republicana contribuyó a una espontánea catolización del conflicto de la que la Iglesia y los nacionalistas se beneficiaron extraordinariamente. La guerra fue caracterizada por los sublevados como una Cruzada. Tenía para ellos un carácter religioso, era una guerra en defensa de la catolicidad,

13 Hemos encontrado muchos modelos de estas insignias y emblemas patrióticos en el Archivo General de la Administración, ya que todas las empresas comerciales que quisieran fabricarlos y venderlos estaban obligadas a obtener previamente la autorización de la Delegación Nacional de Propaganda que sometía todos estos objetos y artículos a censura. Véase, AGA, (3) 48 21/ 55-65. 


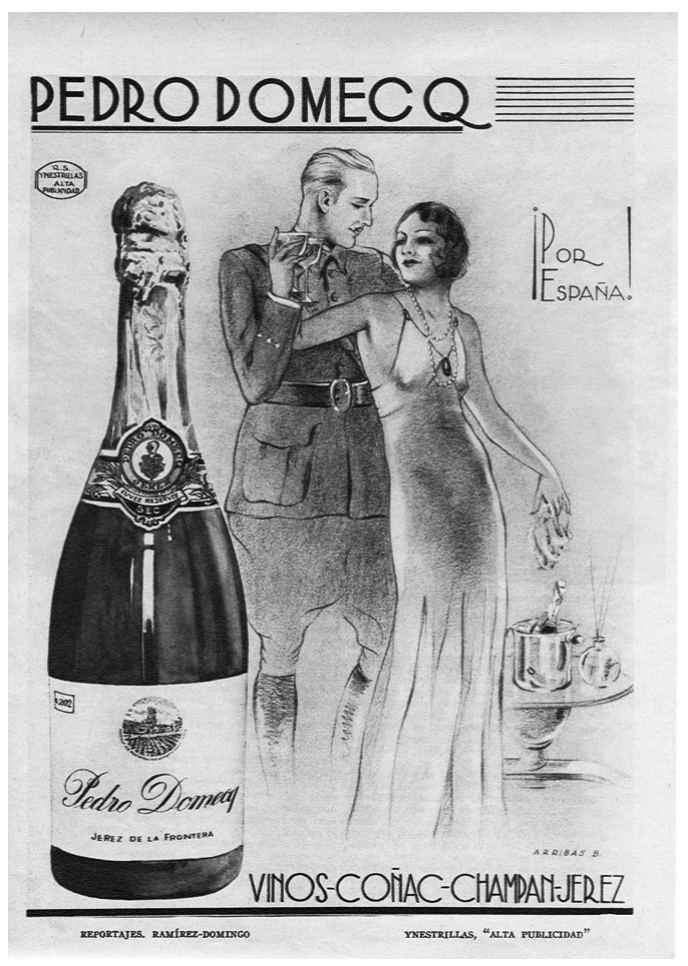

una guerra donde la religión debía triunfar sobre la herejía. Frente a la anti-España del laicismo republicano, la restauración de las formas más tradicionales de religiosidad fue uno de los rasgos característicos de la nueva España franquista. Frente al ateísmo materialista, la «España auténtica» debía ser «baluarte inexpugnable de la fe católica» ${ }^{14}$. La reafirmación nacionalcatólica, la configuración de un Estado católico, acabó siendo para el bando nacional uno de los objetivos básicos de la guerra. De hecho, la zona sublevada experimentó enseguida una profunda recatolización de la vida pública y privada. Por ejemplo, un decreto de 1938 prohibió poner a los recién nacidos nombres que no figurasen en el santoral de la Iglesia católica. Se restableció el crucifijo en las escuelas y en las Audiencias; se derogó la ley republicana del matrimonio civil y del divorcio, se restableció la Compañía de Jesús, se prohibió la coeducación en las escuelas, se estableció una rígida censura de prensa mediante una ley, de abril de 1938, de carácter totalitario que iba a estar vigente hasta los años 60 . Incluso la radio se convirtió en púlpito

${ }_{14}$ Poco después de la victoria, el Papa Pío XII señalaba que en España, «baluarte inexpugnable de la fe católica», habían vencido «los valores eternos de la religión frente a los prosélitos del ateísmo materialista» y que «el sano pueblo español» había sabido «resistir el empuje de los que, engañados por los que los envenenaron hablándoles de un ideal de exaltación de los humildes, lucharon en provecho del ateísmo». Mensaje radiado de 16 de abril de 1939 recogido en $A B C$ el día 18. 
evangelizador con múltiples emisiones religiosas, charlas de orientación, consultorios religioso-morales, rezos, sermones, oraciones radiadas, etc ${ }^{15}$. Todo era católico en la España nacional, pero no por eso dejó de haber tensiones entre el Partido y la Iglesia porque uno y otra tenían voluntad de ocupar todos los espacios.

El final de la guerra coincidió con la Semana Santa (imágenes 50-51), lo que produjo una apoteosis de fervor religioso. Los cereros, imagineros, fabricantes de estampitas, escapularios, rosarios, mantillas, hábitos religiosos... proliferaron, así como los talleres de arte sagrado, improvisados escultores y orfebres de efigies religiosas, fabricantes de santos y vírgenes en serie (imagen 52). El libro religioso tuvo una difusión sin precedentes: devocionarios, misales, vidas de santos, de místicos, de teólogos... alcanzaron tiradas fabulosas.

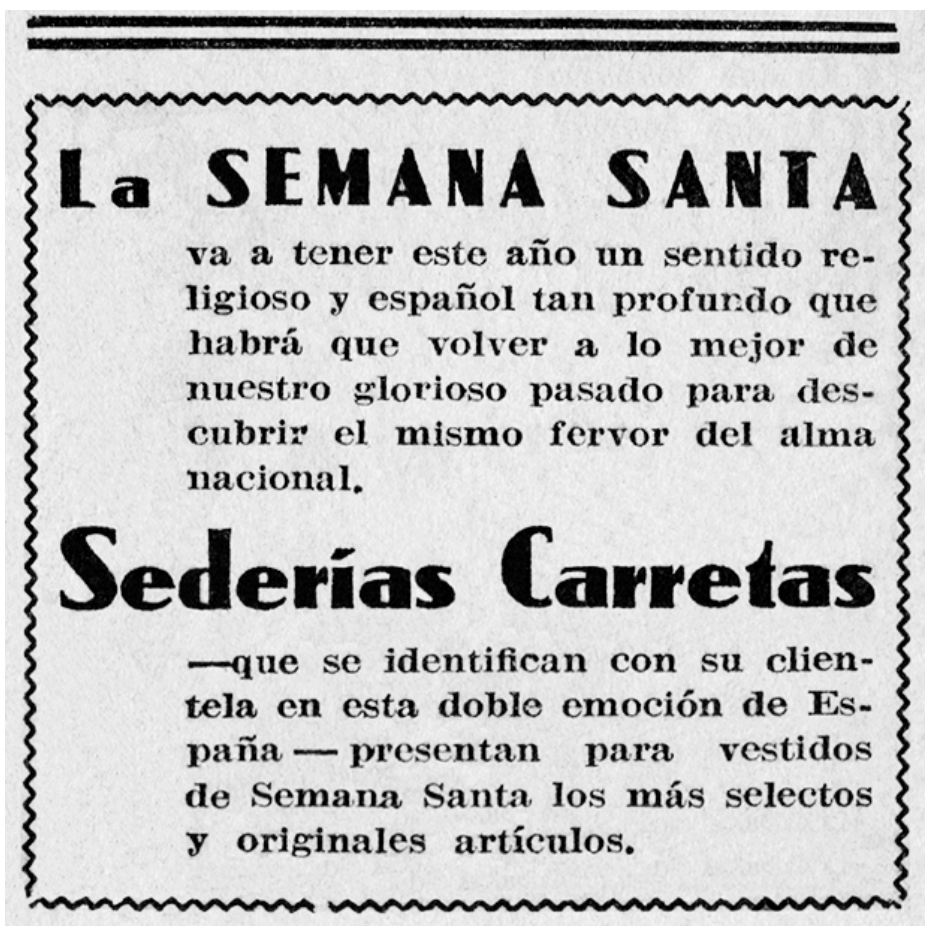

La publicidad comercial utilizó hasta la saciedad el reclamo religioso. Vírgenes, santos y sagrados corazones fueron la imagen y el nombre de toda clase de productos y fábricas; las hay de turrones y mazapanes, de azafrán y pimentón, de conservas, de vinos, de alpargatas, etc., etc. (imagen 53). Las estampas publicitarias de

15 Son muchos los autores que han recordado en sus obras y memorias aquel fervor religioso. Véanse, por ejemplo, BARRAL, C.: Años de penitencia. Madrid, Alianza, 1975; AVIA, A.: De puertas adentro. Memorias. Taurus, 2004; GUBERN, R.: Viaje de ida. Barcelona, Anagrama, 1997; MARTÍNEZ SARRIÓN, A.: Infancia y corrupciones (Memorias, I). Madrid, Alfaguara, 1993; UMBRAL, F.: Memoria de 
productos farmacéuticos se parecían mucho a los recordatorios de primera comunión, con un niño Jesús, un niño pastor o Jesús celebrando la última cena, anunciando ungüentos, jarabes o píldoras. Aunque parezca irreverente (imagen 54), los promotores de estas campañas solían ser de una religiosidad extrema y sus estampitas anunciando sus preparados, una manifestación piadosa de su fe ${ }^{16}$.

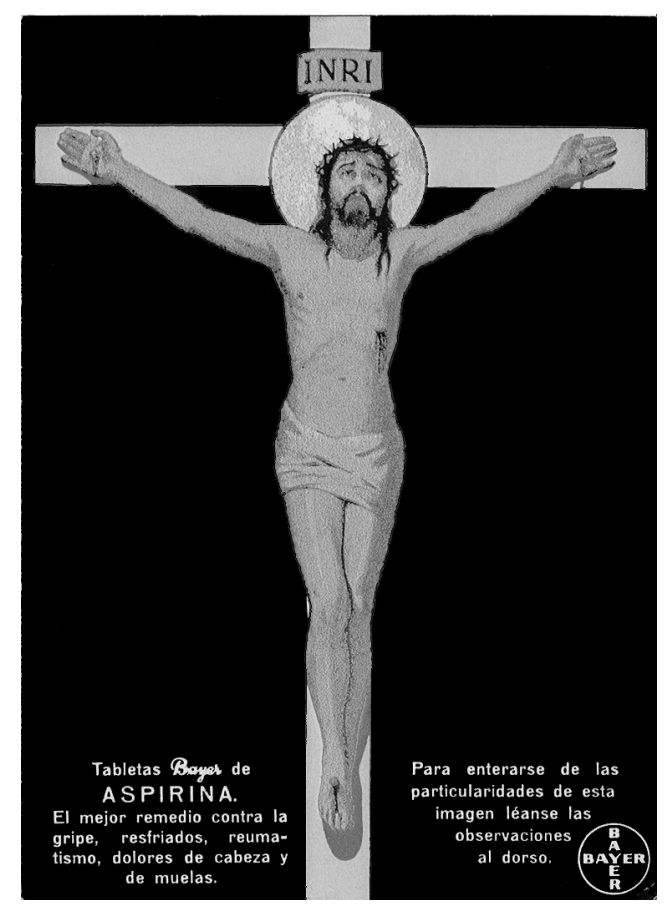

La Iglesia, además, con el decidido apoyo de la autoridad civil, iba a velar celosamente por la moral pública (y privada). Uno de los principales objetivos del bando franquista fue la regeneración de la sociedad partiendo de la idea de que la República había subvertido todos sus valores, en un imparable proceso de disolución iniciado por el liberalismo. En esos planes regeneradores, sobresalieron las medidas destinadas a la moralización de la población, que coincidían con la misión re-

un niño de derechas. Barcelona, Destino, 1980 (1ª ed.: 1972); CARANDELL, J. M.: «Lejos de nosotros la funesta manía de pensar», Cuadernos de Pedagogía, Suplemento 3, 9-1976. Véase también, CÁMARA VILLAR, G.: Nacionalcatolicismo y escuela. Madrid, Hesperia, 1984. SÁNCHEZ ERAUSKIN, J.: Por Dios hacia el Imperio. Nacionalcatolicismo en las Vascongadas del primer franquismo. 1994. URBINA, F.: «Formas de vida de la Iglesia en España, 1939-1975». En Iglesia y Sociedad en España, 19391975. Madrid, 1977. FUSI, J. P.: «Educación y cultura». En Historia de España Menéndez Pidal, «La época de Franco (1939-1975). Sociedad, vida y cultura». Madrid, Espasa Calpe, 2001.

16 Véase, PUERTO SARMIENTO, F. J.: El medicamento en el escaparate. La publicidad farmacéutica en España. Una aproximación histórico-literaria. Barcelona, Fundación Uriach/Ediciones Mayo, 2004. 
cristianizadora asumida por la Iglesia ya que se sobrentendía que no había otra moral al margen de la católica ${ }^{17}$.

Hubo una obsesión por combatir la «inmoralidad» en todas sus manifestaciones, con múltiples medidas contra la relajación de las costumbres. Entre ellas, tuvieron especial importancia las campañas para la represión de la blasfemia, «lacra social muy extendida que hiere los sentimientos religiosos de la mayoría del país". Se editaron multitud de carteles o avisos fijados en los tranvías y otros lugares con lemas como «blasfemar es injuriar a Dios y deshonrar a España» (imagen 55). Las interjecciones soeces, las frases obscenas y, en general, las actitudes juzgadas «desvergonzadas» serían en adelante objeto de multas y publicación en la prensa del nombre de los sancionados.

La Iglesia se erigió en la máxima controladora de la castidad, pureza y decencia de la sociedad y, muy en concreto, de la mujer, ya que se argumentaba que, dada la impresionable e imaginativa psicología femenina, era ella sobre todo la que debía ser apartada de las tentaciones mundanas como el baile moderno (imagen 56), la playa o el cine. Al acercarse la estación estival, y en defensa de la moralidad pública, comenzaron a hacerse públicas notas prohibiendo el uso de prendas de baño indecorosas, exigiendo que los bañadores cubriesen el pecho y espaldas debidamente, además de estar dotados de faldas en los bañadores de mujeres y pantalón de deporte en el caso de los hombres. Quedaba también prohibido tomar el sol sin albornoz.

Las normas impuestas por la Iglesia, de una moral anacrónica, mojigata y demonizadora, tuvieron sobre todo a la mujer como objetivo. Ni vestidos ceñidos o demasiado estrechos, ni demasiado cortos, ni demasiado escotados. Si la mujer de los años treinta se había liberado de la faja-tubo, con el franquismo volvieron los corsés, corpiños y ballenas. Tampoco ninguna mujer decente debía ser vista en pantalones largos; para salir a la calle y, desde luego, para ir a la iglesia, nada de tirantes o manga corta y, por supuesto, nada de ir sin medias. Las medias eran obligatorias para las niñas a partir de los doce años, según las normas de moral imperantes. La mujer decente debía de controlar, además de sus ropas, su manera de proceder en público. No debía cruzar las piernas al sentarse, no estaba bien visto que fumase y no llevaría el pelo suelto sino recogido y peinado con ondulaciones y rizos. Las lacias melenas cayendo por la espalda y los hombros eran verdadero anatema porque recordaban a las milicianas republicanas.

El discurso franquista se caracterizó por la desigualdad de hombre y mujer. Niñas y niños debían recibir una educación por separado, ellos orientados al ámbito profesional, ellas al doméstico (imagen 57). El mantenimiento del hogar y la maternidad y cuidado de los hijos eran las misiones exclusivas de las mujeres (imágenes 58-59).

17 MORADIELLOS, E: La España de Franco (1939-1975). Política y Sociedad. Madrid, Editorial Síntesis, 2000, p. 118. 


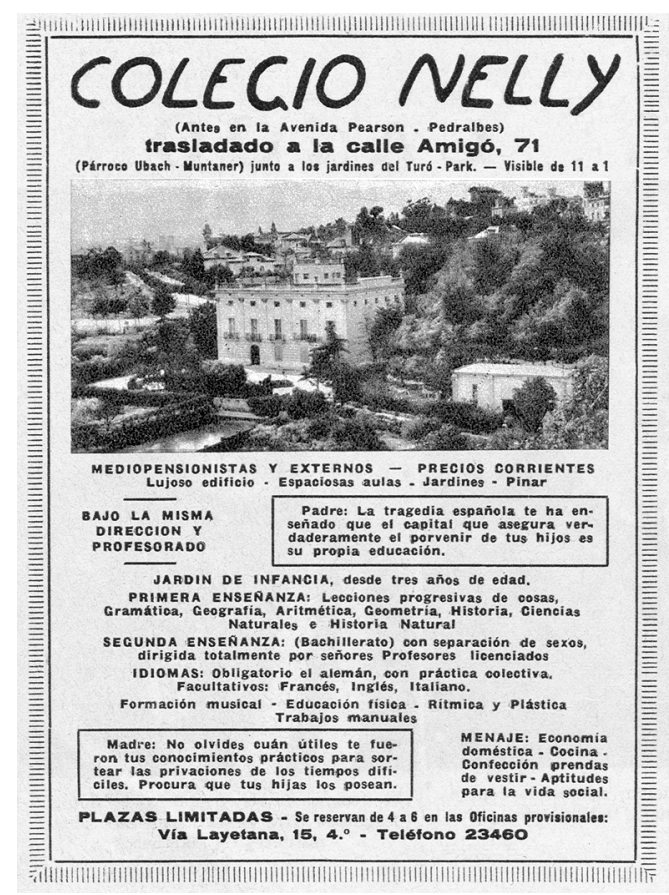

La mujer española debía ser hacendosa, discreta, humilde, recatada, comedida, tradicional. La demonización y ridiculización de una mujer distinta -independiente, trabajadora - iba a ser sistemática. En el seno de la familia franquista se reproducen las relaciones jerárquicas de la sociedad. Un modelo de familia basado en los valores de autoridad, disciplina, obediencia y sumisión. La única felicidad legítima para la mujer era la dependencia del varón. Su sumisión, al padre primero, y al marido después. Las mujeres debían dejarse guiar por la voluntad más fuerte y la sabiduría del hombre. En numerosas obras sobre normas de educación femenina se decía que la mujer tenía una natural disposición al sacrificio y la abnegación.

Este modelo de mujer franquista está, por supuesto, muy presente en la publicidad comercial, como lo está la imagen de un hombre «de orden», siempre bien vestido, con camisa, corbata, chaqueta y sombrero; bien afeitado, bien peinado, con un esmerado corte de pelo. La publicidad muestra esa imagen de un hombre indefectiblemente trajeado y engominado (imagen 60). Si en la zona republicana muchos dejaron de llevar corbata, cuello en la camisa y sombrero, en la nacional el reto insolente fue no llevarlos. Un diario falangista de San Sebastián ya advirtió en mayo de 1937 cómo serían las cosas en la España de Franco: «Se han empezado a ver signos de gamberrismo representado por personas, casi siempre jóvenes, a quienes su vigor físico no les permite, por lo visto, soportar el grave peso de la americana en días de calor y se la quitan, paseándose en mangas de camisa. Bajo 
ningún concepto se ha de tolerar semejante costumbre y quienes se obstinen en querer evocarnos, de esta manera, los deplorables tiempos de plebeyez del frente soviético popular, serán fuertemente sancionados» ${ }^{18}$. En efecto, al llegar el verano, los bandos de los gobernadores civiles recordarían la prohibición tajante de que, tanto en locales cerrados como en las terrazas de los cafés y bares, quedasen los caballeros en mangas de camisa ya que, de hacerlo, dejarían de serlo y se les multaría con cinco pesetas.

Y, por supuesto, el caballero de la España nacional debía llevar sombrero. Si en la España republicana habían dejado de verse sombreros por las calles, y todo fue profusión de gorras proletarias, o boinas a todo lo más, en la España de Franco se condenó el «sinsombrerismo". De ahí que en el año 39, un avispado sombrerero inventase un eslogan que hizo que subieran enormemente las ventas de su negocio: "Los rojos no usaban sombrero» (imagen 61).

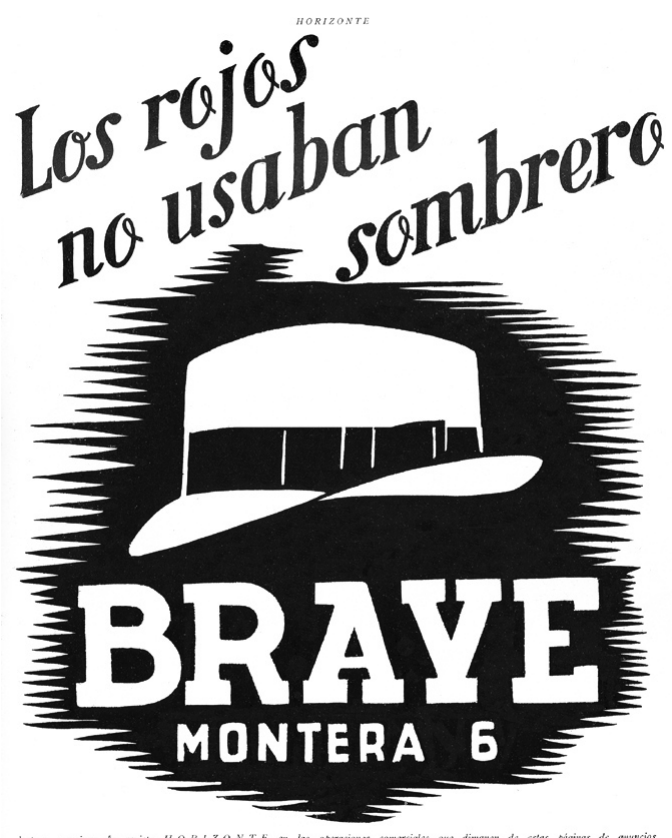

18 Unidad. Diario falangista. San Sebastián, 26 de mayo de 1937. 